\title{
Two unusual new species of the ostracod genus Cytheropteron from the Late Cainozoic of the deep sea
}

\author{
ROBIN WHATLEY, MICHAEL AYRESS \& SIAN DOWNING \\ Micropalaeontology Division, Department of Geology, University College of Wales, Aberystwyth, U.K.
}

\begin{abstract}
Two new deep sea species of the genus Cytheropteron $(C$. branchium and C. pherozigzag spp. nov) are described. Both species occur in abyssal and bathyal Pliocene to Quaternary environments in the S. W. Pacific; the latter species has also been recovered from abyssal palaeodepths in the N.E. Atlantic and E. Indian Ocean in the Late Quaternary. Both species are unusual in possessing shallow yet prominent slit-like structures below and posteroventral to the alar process. Such structures are unknown in other species of the genus; their possible function is discussed.
\end{abstract}

\section{INTRODUCTION}

The two species on which this paper is based were first encountered in Pliocene strata at various D.S.D.P. sites in the S.W. Pacific and subsequently in Quaternary sediments in the same area. Since they never occur abundantly in any one sample, it has taken some years to accumulate sufficient material to allow of their publication. The two species in the S.W. Pacific are found in Pliocene and Pleistocene strata, in the eastern Indian Ocean in the Pleistocene in which strata they have also recently been encountered in the $\mathrm{N}$. Atlantic.

In the S.W. Pacific, Pliocene records of both species are confined to bathyal palaeodepths and both species also occur at these palaeodepths in the Pleistocene. However, C. pherozigzag (but not C. branchium) in the S.W. Pacific Pleistocene, also occurs at abyssal palaeodepths. In the eastern Indian Ocean, C. pherozigzag and C. branchium have been found only in the Pleistocene at depths of $4696 \mathrm{~m}$ and $1253 \mathrm{~m}$ respectively. In the $\mathrm{N}$. Atlantic both species occur in the Quaternary, $C$. branchium only in the abyss; $C$. pherozigzag over a much wider depth range ( $1678 \mathrm{~m}$ to $2414 \mathrm{~m}$ ).

Published accounts of Cytheropteron faunas from deep water Cainozoic environments are almost totally lacking, while studies such as those of Whatley \& Masson (1979), Neale \& Howe (1973) in the North Atlantic and papers by various authors on Mediterranean faunas (Bonaduce et al ., 1975; Colalonga \& Pasini, 1980 etc.) all from shelf depths, have substantially increased our knowledge of the genus in these enviromnents and have indicated its hitherto overlooked high diversity. Current studies on deep water faunas at Aberystwyth have revealed that Cytheropteron is also a major and often very diverse component of deep water faunas. Some 85 species of the genus have been recovered from the Tertiary and Quaternary of the D.S.D.P. sites studied to date in the S.W. Pacific and an indication of this high diversity is given in Whatley (1983, Table 2).
In the deep water Pleistocene of the N. Atlantic, Cytheropteron, while less diverse than in the S.W. Pacific is, nonetheless, a major contributor to the fauna, a conservative estimate being some 35 species. In almost all of the deep water Late Cainozoic samples which we have studied from the world's oceans, Cytheropteron ranks second in diversity after Krithe. In incidence, the genus also ranks high in deep sea ostracod faunas.

The catalogue numbers used in this paper refer to the collections of the Department of Palaeontology, British Museum (Natural History) where the type specimens are deposited.

\section{SYSTEMATIC DESCRIPTIONS}

Phylum Crustacea Pennant, 1977

Class Ostracoda Latreille, 1806

Order Podocopida Müller, 1894

Superfamily Cytheracea Müller, 1894

Family Cytheruridae Baird, 1850

Genus Cytheropteron Sars, 1866

\section{Cytheropteron branchium sp. nov.}

(Pl. 1, figs. 1-5)

Derivation of name. Latin, with reference to the similarity of the slit-like structures posteroventrally in this species to the branchial openings of elasmobranch fishes.

Diagnosis. Medium-sized Cytheropteron with large backward directed alar process, with spinose apex, midlateral punctate ornament, smooth periphery and a series of slit-like structures, 4 vertical and 4 arcuate/ horizontal posteroventrally.

Holotype. Adult right valve, OS 12472 .

Material. 39 specimens, 16 adults, 23 juveniles. Type locality and horizon. S.W. Pacific, D.S.D.P. Site 208, Lord Howe Rise, Lat. 26 06.61' S; Long. $161^{\circ} 13.27^{\prime}$ E. Core 4, Section 4, Interval $7-18 \mathrm{cms}$., 39.5 metres below sea floor. Middle Pliocene, nanno- 
bearing foraminiferal rich calcic ooze. Zone N21 of Blow (1969). Present day water depth, $1545 \mathrm{~m}$.

Description. Medium sized, delicately calcified. Subovate to pyriform in lateral view with large triangular alar process projecting beyond ventral margin. Hastate in dorsal view with alar process having a long convex leading edge and a slightly shorter straight trailing edge; a long apical spine projects posterolaterally. Anterior margin symmetrically convex. Posterior margin with a short slightly upturned caudal process above midheight. Dorsal margin weakly arched in the left valve, more strongly so in the right valve with an anterodorsal concavity. Ventral margin covex with a slight broad oral incurvature. Right valve overhangs left valve dorsally. Ornament comprising small, circular punctae which diminish in size dorsally and which are confined to midthird of valve surface and extending onto base of alar process. The ventral surface is conspicuously ornamented with four vertical slits mid-ventrally beneath the alar process which taper towards ventral margin. Posterior of these are four arcuate/horizontal convex upwards crescentic slits which decrease in length dorsally, and occur in a shallow concave region. The slits are expressed internally both in juvenile and adult valves by prominent raised areas. The slits do not penetrate to the interior. A weak ridge extends a short distance along postero-alar surface from the base of the apical spine. Normal pore canals few, small and open. Inner lamella wide anteriorly, moderately wide posteriorly, narrow ventrally. Selvage distinctly fluted posteroventrally. Anterior vestibulum wide, crescentic; posterior small. Radial pore canals moderately long, straight and simple; approximately seven anteriorly, three posteriorly. Muscle scars consist of a closely adjacent subvertical row of four sub-ovate adductors and a V-shaped frontal scar. Hinge antimerodont; left valve terminal elements are shallow loculate sockets, median element a long gently convex denticulate bar, the denticles moderately increasing in size anteriorly and posteriorly.

Dimensions. (mm) Length Height

Holotype RV OS 12472 Site 208/4/4 M. Pliocene

$0.52 \quad 0.30$

Paratype RV OS 12473 Site 207/5/4 M. Pliocene

$0.51 \quad 0.29$

Paratype LV OS 12474 Site 209/1/5 M. Pleistocene

$0.50 \quad 0.30$

Paratype RV OS 12475 Site 209/1/1 U. Pleistocene $0.54 \quad 0.30$

Paratype RV OS 12476 Site 208/2/3 M. Pleistocene

$$
0.53 \quad 0.30
$$

Remarks. Atlantic Upper Pleistocene specimens differ from those from the Plio/Pleistocene of the S.W. Pacific in being proportionally higher, in their smaller punctae mid-laterally and in possessing punctae on the ventral surface beneath the leading edge of the alar process.
They also bear small rather bulbous spines along the trailing edge of the alar process which are absent in S.W. Pacific specimens. There is also a slight difference in the spacing between the posterior ventral horizontal/ arcuate slits.

C. branchium differs from C. pherozigzag in that the latter is smooth, has a less rounded anterior margin, is proportionally lower and has a zigzag rather than horizontal/arcuate disposition of its posterior slit-like structures.

Distribution. The species ranges from the Middle Pliocene to the Upper Pleistocene. Details of its occurrence are given in Table 1.

$$
\text { Cytheropteron pherozigzag sp. nov. }
$$

(Pl. 1, figs. 6-20)

Derivation of name. Latin and French. With reference to the zigzag shaped slit-like processes which this species bears posteroventrally.

Diagnosis. A medium-sized Cytheropteron with prominent and very flattened backward directed alar process, smooth centrolateral surface and a series of slitlike structures posteroventrally of which two are vertical, one L-shaped and 4 chevron-like and zigzag shaped in a horizontal plane posteriorly.

Holotype. Adult right valve, OS 12477.

Material. 60 specimens, 21 adults, 39 juveniles.

Type locality and horizon. N. Atlantic, Denmark Strait, Lat., $64^{\circ} 02^{\prime} \mathrm{N}$; Long. $28^{\circ} 57^{\prime} \mathrm{W}$; NATO borehole S3, Level: $59-62 \mathrm{~cm}$. Late Quaternary, olive grey fine sediment, present day water depth $1690 \mathrm{~m}$.

Description. Medium-sized, delicately calcified. Subovate to pyriform in lateral view with large triangular alar process projecting beyond ventral margin. Hastate in dorsal view with alar process having a long, straight, rimmed leading edge and slightly shorter, straight trailing edge bearing seven short weak spines, equidistanced along its length; long backward projecting apical spine continuous with leading edge of alar process. Anterior margin strongly convex anteroventrally, tapering dorsally. Posterior margin with a short, broad caudal process just above mid-height in right valve, subdorsal in left valve. Dorsal margin weakly arched to gently undulating in the left valve, more strongly arched in the right valve with a shallow concavity anteriodorsally. Ventral margin convex with a slight oral incurvature. Right valve overhangs left valve dorsally. Ventral surface beneath alar process conspicuously ornamented with three vertical slits, the anterior-most slit is L-shaped, the remainder taper to a point near the ventral margin. Posterior of these, four horizontal chevron-shaped zigzag slits occur, the lower two extending and tapering anteriorly towards the vertical slits; the area between each horizontal slit is hollowed and enclosed by two heart-shaped elevated domed areas, so that the posteroventral region comprises two columns of four of these domed structures. The number of slits increase at each 


\begin{tabular}{|c|c|c|c|c|c|c|c|}
\hline \multicolumn{8}{|c|}{ S.W. Pacific } \\
\hline & \multirow[b]{2}{*}{ Long. } & \multicolumn{2}{|c|}{ PDWD DSDP } & \multirow[b]{2}{*}{ Core } & \multirow[b]{2}{*}{ Section } & \multirow[b]{2}{*}{ Interval } & \multirow[b]{2}{*}{ Age } \\
\hline Lat. & & $\mathrm{m}$ & Site & & & & \\
\hline $23^{\circ} 06.61^{\prime} \mathrm{S}$ & $161^{\circ} 13.27^{\prime} \mathrm{E}$ & 1545 & 208 & 2 & 3 & $135-140$ & M. Pleist. \\
\hline \multirow[t]{3}{*}{$15^{\circ} 56.19^{\prime} \mathrm{S}$} & \multirow[t]{3}{*}{$152^{\circ} 11.27^{\prime} \mathrm{E}$} & 1428 & 209 & 1 & 1 & $75-80$ & U. Pleist. \\
\hline & & & 209 & 1 & 5 & $75-80$ & M. Pleist. \\
\hline & & & 209 & 2 & 2 & $75-80$ & M. Pleist. \\
\hline \multirow[t]{5}{*}{$30^{\circ} 58.15^{\prime} \mathrm{S}$} & \multirow[t]{5}{*}{$87^{\circ} 53.72^{\prime} \mathrm{E}$} & 1253 & 254 & 1 & 3 & $50-56$ & M. Pleist. \\
\hline & & & 208 & 3 & 3 & $135-140$ & U. Plio. \\
\hline & & & 208 & 4 & 2 & $65-70$ & U. Plio. \\
\hline & & & 208 & 4 & 4 & $7-18$ & M. Plio. \\
\hline & & & 208 & 5 & 6 & $7-18$ & M. Plio. \\
\hline \multirow[t]{2}{*}{$36^{\circ} 57.75^{\prime} \mathrm{S}$} & \multirow[t]{2}{*}{$165^{\circ} 26.06^{\prime} \mathrm{E}$} & 138 & 207 & 5 & 4 & $15-22$ & M. Plio. \\
\hline & & \multicolumn{4}{|c|}{ B. North Atlantic } & & \\
\hline Lat. & Long. & $\begin{array}{c}\text { PDWD } \\
\mathrm{m} .\end{array}$ & $\begin{array}{l}\text { NATO } \\
\text { Core }\end{array}$ & \multicolumn{2}{|c|}{$\begin{array}{l}\text { Depth below } \\
\text { seabed }\end{array}$} & \multicolumn{2}{|c|}{ Age } \\
\hline $34^{\circ} 08^{\prime} \mathrm{N}$ & $39^{\circ} 02^{\prime} \mathrm{W}$ & \multirow[t]{3}{*}{2880} & 14 & \multirow{3}{*}{\multicolumn{2}{|c|}{$\begin{array}{c}13.5-21.5 \mathrm{~cm} \\
45-50 \\
145-150\end{array}$}} & \multirow{3}{*}{\multicolumn{2}{|c|}{$\begin{array}{l}\text { Late Quaternary } \\
\text { Late Quaternary } \\
\text { Late Quaternary }\end{array}$}} \\
\hline $34^{\circ} 08^{\prime} \mathrm{N}$ & $39^{\circ} 02^{\prime} \mathrm{W}$ & & 14 & & & & \\
\hline $34^{\circ} 08^{\prime} \mathrm{N}$ & $39^{\circ} 02^{\prime} \mathrm{W}$ & & 14 & & & & \\
\hline
\end{tabular}

Table 1. Details of the distribution of C. branchium sp. nov.

moult in ontogeny; the A-3 instar has only two horizontal, two vertical and part of the L-shaped slit. These structures are reflected internally in juveniles but the slits do not penetrate to the interior. Adult valves do not seem to exhibit these structures internally. This area, however, is partly obscured by the inner lamella in adults. The lateral surface also bears a short low ridge near to and parallel to the dorsal margin posteriorly, otherwise it is smooth. Normal pore canals few, small and open. Inner lamella of medium width at end margins; anterior vestibulum small, crescentic; posterior vestibulum narrow. Radial pore canals straight, simple; seven anteriorly, three posteriorly. Muscle scars a closely adjacent subvertical row of four subovate adductors and a V-shaped frontal scar. Hinge antimerodent with, in the left valve, shallow delicately incised loculate terminal sockets and a long arcuate median element denticulate throughout but most strongly distally.

Dimensions. (mm) Length Height Holotype RV OS 12477 NATO Core S3 Level
59-62 L. Quat.
$0.57 \quad 0.32$

Paratype RV OS 12478 NATO Core S3 Level
59-63 L. Quat.
0.52
0.30

Paratype LV OS 12479 NATO Core Balen Level
14-22
L. Quat.
0.61
0.33

Paratype LV OS 12480 DSDP Site 209/1/1 U. Pleistocene $0.54 \quad 0.32$

Paratype RV OS 12481 NATO Core S3 Level 45-90 L. Quat. $\quad 0.57 \quad 0.31$

Paratype LV OS 12482 NATO Core R3 Level $\begin{array}{llll}100-105 & \text { L. Quat. } & 0.60 & 0.31\end{array}$

Remarks. The chevron-shaped zigzag posteroventral slits distinguish this species from C. branchium sp. nov. and from all other species of the genus. In general shape, ornament and the shape and attitude of the alar process, $C$. pherozigzag resembles such species as $C$. alatum Sars, C. vespertilio (Reuss) and C. volantium Whatley \& Masson. All these latter species, however, lack posteroventral slits.

Distribution. The species ranges from the Lower Pliocene to the late Quaternary. Details of its occurrence are given in Table 2.

DISCUSSION. While it is not uncommon for species of Cytheropteron to exhibit ornament which differs from that of the rest of the carapace along their ventral or posteroventral margins (e.g. C. elofsoni Lord, 1981 and a number of species described by Colalonga \& Pasini, 1980), the possession of slit-like structures is unique to the two species described herein. The authors, 
A. S. W. Pacific and E. Indian Ocean

\begin{tabular}{cccccccl} 
Lat. & \multicolumn{9}{c}{ PDWD DSDP } & & & & \\
& Long. & $\mathrm{m}$. & Site & Core & Section & Interval & Age \\
\hline $26^{\circ} 06.61^{\prime} 5 ;$ & $161^{\circ} 13.27^{\prime} \mathrm{E}$ & 1545 & 208 & 2 & 3 & $135-140$ & U. Pleist. \\
$15^{\circ} 56.19^{\prime} \mathrm{S} ;$ & $152^{\circ} 11.27^{\prime} \mathrm{E}$ & 1428 & 209 & 1 & 1 & $75-80$ & U. Pleist. \\
& & & 209 & 1 & 5 & $75-80$ & M. Pleist. \\
& & & 209 & 2 & 6 & $75-80$ & L. Pleist. \\
$10^{\circ} 52.19^{\prime} \mathrm{S} ;$ & $123^{\circ} 50.78^{\prime} \mathrm{E}$ & 2298 & 262 & 25 & 2 & $5-10$ & M. Pleist. \\
$22^{\circ} 09.22^{\prime} \mathrm{S} ;$ & $117^{\circ} 32.77^{\prime} \mathrm{W}$ & 2720 & 203 & 1 & 1 & $95-100$ & U. Pleist. \\
& & & 203 & 1 & 4 & $60-68$ & M. Pleist. \\
$26^{\circ} 06.61^{\prime} \mathrm{S} ;$ & $161^{\circ} 13.27^{\prime} \mathrm{E}$ & 1545 & 208 & 7 & 5 & $15-25$ & L. Plio. \\
& & & 208 & 8 & 5 & $6-16$ & L. Plio. \\
$33^{\circ} 47.69^{\prime} \mathrm{S} ;$ & $112^{\circ} 28.42^{\prime} \mathrm{E}$ & 2793 & 258 & 3 & 1 & $62-69$ & U. Plio. \\
$29^{\circ} 37.05^{\prime} \mathrm{S} ;$ & $112^{\circ} 41.78^{\prime} \mathrm{E}$ & 4696 & 259 & 1 & 4 & $12-18$ & M. Pleist.
\end{tabular}

B. North Atlantic (all Upper Quaternary)

\begin{tabular}{|c|c|c|c|c|}
\hline Lat. & Long. & $\begin{array}{c}\text { PDWD } \\
\mathrm{m} .\end{array}$ & $\begin{array}{l}\text { NATO } \\
\text { Core }\end{array}$ & $\begin{array}{l}\text { Depth below } \\
\text { Sea Bed cm. }\end{array}$ \\
\hline $60^{\circ} 58^{\prime} \mathrm{N}$ & $20^{\circ} 58^{\prime} \mathrm{W}$ & 2177 & R3 & $\begin{array}{c}50-55 \\
100-105 \\
155-160\end{array}$ \\
\hline $60^{\circ} 54^{\prime} \mathrm{N}$ & $13^{\circ} 05^{\prime} \mathrm{W}$ & 1678 & $\mathrm{R} 2$ & $\begin{array}{l}100-105 \\
155-160\end{array}$ \\
\hline $64^{\circ} 02^{\prime} \mathrm{N}$ & $28^{\circ} 57^{\prime} \mathrm{W}$ & 1690 & $\mathrm{~S} 3$ & $\begin{array}{c}4.5-9.0 \\
59-62\end{array}$ \\
\hline $34^{\circ} 56^{\prime} \mathrm{N}$ & $08^{\circ} 09^{\prime} \mathrm{W}$ & 2414 & Balen & $\begin{array}{c}14-22 \\
100-110\end{array}$ \\
\hline $\begin{array}{l}10^{\circ} 00^{\prime} \mathrm{N} \\
28^{\circ} 02^{\prime} \mathrm{N}\end{array}$ & $\begin{array}{l}56^{\circ} 47^{\prime} \mathrm{W} \\
72^{\circ} 40^{\prime} \mathrm{W}\end{array}$ & $\begin{array}{l}3696 \\
4923\end{array}$ & $\begin{array}{l}\text { A } 4 \\
\text { G } 5\end{array}$ & $\begin{array}{c}140-145 \\
80-85 \\
180-185\end{array}$ \\
\hline
\end{tabular}

Table 2. Details of the distribution of $C$. pherozigzag sp. nov.

\section{Explanation of Plate 1}

Figs. 1-5. Cytheropteron branchium sp. nov.

Figs. 1, 2. Holotype ARV, OS 12472 DSDP site 208, core 4, section 4. M. Pliocene: fig. 1, ext. lat. ( $\times 173)$; fig. 2, oblique mid-vent. $(\times 381)$.

Fig. 3. A-1 LV, UCW/0/1013, ext. lat. (×225). DSDP site 208, core 4, section 4. M. Pliocene.

Fig. 4. Paratype 2 ARV, OS 12475, int. lat. $(\times 167)$. DSDP site 209 , core 1 , section 1 . U. Pleistocene.

Fig. 5. Paratype 1 ARV, OS 12473, int. lat $(\times 200)$. DSDP site 207, core 5, section 4. M. Pliocene.

Figs. 6-20. Cytheropteron pherozigzag sp. nov.

Fig. 6. Paratype 2 ALV, OS 12479 , eat. lat. $(\times 148)$. Nato core Balen. Late Quaternary.

Fig. 7. Paratype 4 ARV, OS 12481 , ext. lat. $(\times 158)$. Nato core S3. Late Quaternary.

Figs. 8, 9, 11, 12, 14, 17. Holotype ARV, OS 12477, Nato core S3. Late Quaternary: fig. 8, ant. $(\times 160)$; fig. 9, post. $(\times 180)$; fig. 11 , oblique mid-vent. $(\times 375)$; fig. 12 , vent. $(\times 170)$; fig. 14 , oblique ant. vent. $(\times 240)$; fig. 17 , post. vent, horiz. slits $(\times 800)$.

Fig. 10. ALV, UCW/0/1014, ext. lat. $(\times 161)$. Nato core S3. Late Quaternary.

Fig. 13. Paratype 1 ARV, OS 12478 , int. lat. $(\times 173)$. Nato core S3. Late Quaternary.

Figs. 15, 16. Paratype 3, ALV, OS 12480, DSDP site 209, core 1, section 1. U. Pleistocene: fig. 15, detail of abraded ventral margin $(\times 663)$; fig. 16 , ext. lat. $(\times 175)$.

Fig. 18. A-3 RV, UCW/0/1015, vent. lat. $(\times 290)$. DSDP site 262 , core 25 , section 2. M. Pleistocene.

Fig. 19. Broken A-1 LV, UCW/0/1016, int. lat. ( $\times 200)$. DSDP site 208, core 7, section 5. Early Pliocene.

Fig. 20. A-2 LV, UCW/0/1017, int. lat. $(\times 240)$. DSDP site 262 , core 25 , section 2 . M. Pleistocene. 


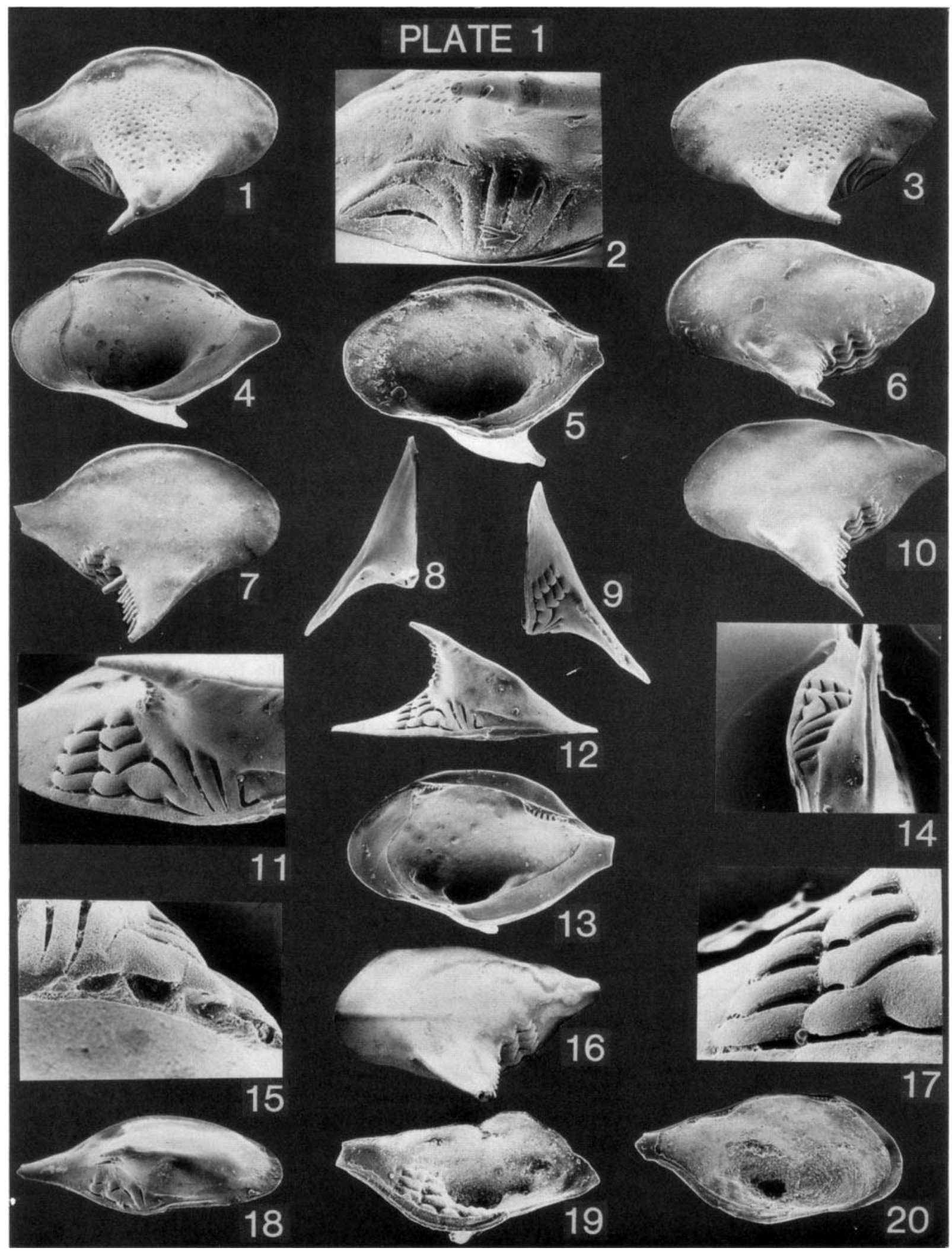


after an exhaustive search of the literature have failed, not only to encounter these structures in any other species of Cytheropteron, but in any other ostracod.

In both $C$. branchium and $C$. pherozigzag the slitlike structures represent a major modification of the carapace. This clearly implies a functional relationship. The nature of the function of these structures, however, is difficult to ascertain. If the slits penetrated the carapace, thereby allowing access to the interior, it would be much easier to suggest a function perhaps related to feeding or respiration. However, since the slits are blind, it is unlikely that their function was associated with either of these two processes. In juveniles, the external slits are strongly reflected as elevations on the inner surface of the valve. In the adult, most of these internal structures would lie in the plane of fusion between the two lamellae, the posterior vestibulum in this region being very narrow. Since the internal structures are concealed by the inner lamella in the adult stage, they can have no functional significance to the mature animal and it is doubtful, therefore, that they had any function in ontogeny. We prefer to consider these structures merely as an internal reflection of external carapace features.

We have considered the possibility that the external slits were either primarily or secondarily sexual in function. Could C. brachium and C. pherozigzag be male or female dimorphs and could we have overlooked the other sex of both species? Sexual dimorphism is almost impossible to detect in the carapace morphology of Cytheropteron. We have carefully examined the other species of the genus in all the samples from which the two species have been recovered in an attempt to find specimens of otherwise similar size, shape, alar development and ornament but lacking the slit-like structures. No such specimens have been found. Indeed, we found no specimens of Cytheropteron in these and associated samples which we could even consider as unlikely missing dimorphs of the two species. Equally, we reject the possibility, on morphological grounds and on the disparity of occurrence, that $C$. branchium and $C$. pherozigzag are dimorphs of the same species.

We are obliged to conclude, therefore, that both sexes of both species bear the same structure and that, therefore, their function cannot be sexual. Although our records of both species extend only to the end of the Pleistocene, it is highly probable that both are still living. Possibly they will eventually be encountered live in Recent sediments. Only a study of the appendage morphology would resolve their sexual status.

Our only suggestion as to the function of these structures is that they are in some way associated with the hydrodynamics of the animal. Possibly they are a device whose function is to increase the turbulence of the water flowing past the carapace, perhaps more efficiently to remove waste products from the animal's immediate environment. We do not understand why, in both species, those slits immediately beneath the alar process are vertical and why those behind the alae are arcuate/ horizontal. Could the slits possibly have housed symbionts perhaps associated with feeding, removal of waste products or the production of light by bioluminescence? The absence of perforations would militate against the structures being associated with large setae. Their presumed occurrence in both sexes argues against their being devices for the external incubation of fertile eggs, as does their morphology. Frankly, we are unable to define their function.

\section{ACKNOWLEDGEMENTS}

Downing wishes to acknowledge N.E.R.C. for the studentship held during the course of this research. The paper was typed by Marian Mayes. We would also like to thank Christine Porter and Wil Harpur for allowing us access to their research material.

\section{Manuscript received August 1984 Revised manuscript accepted March 1985}

\section{REFERENCES}

Bonaduce, G., Ciampo, G. \& Masoli, M. 1975. Distribution of Ostracoda in the Adriatic Sea. Publ. Staz. Zool. Napoli., 40 Suppl., 1-304.

Colalongo, M. S. \& Pasini, G. 1980. La Ostracofauna plio pleistocenica della Sezione Vrica in Calabria (con considerazioni sul limite Neogene/Quaternario). Boll. Soc. Palaeontol. Italiana 19 (1), 44-126.

Lord, A. 1981. On Cytheropteron elofsoni Lord sp. nov. Stereo-Atlas of Ostracod Shells, 8 (6), 33-36.

Neale, J. W. \& Howe, H. V. 1973. New coldwater Recent and Pleistocene species of the ostracod genus Cytheropteron. Crustaceana, 25, 237-244.

Whatley, R. C. 1983. Some aspects of the palaeobiology of Tertiary deep-sea Ostracoda from the S.W. Pacific. J. micropalaeontol, 2, 83-104.

Whatley, R. C. \& Masson, D. G. 1979. the ostracod genus Cytheropteron from the Quaternary and Recent of Great Britain. Rev. Exp. de Micropaleontol., 11 (2), 223-277. 